\title{
Literatura, política e legitimação institucional: o romance de 1930 e 0 modernismo de 1922 segundo a retórica estadonovista
}

\author{
Thiago Mio Salla
}

\begin{abstract}
RESUMO: O presente artigo propõe-se a recuperar o modo por meio do qual alguns intelectuais vinculados ao Estado Novo brasileiro - Almir de Andrade, Rosário Fusco e Wilson Lousada, entre outros - promoveram uma leitura teleológica do modernismo de 1922, bem como procuraram apropriar-se do romance regionalista de 1930 como meios de legitimar a chegada e a permanência de Vargas no poder.
\end{abstract}

PALAVRAS-CHAVE: romance de 1930; modernismo de 1922; Estado Novo; Graciliano Ramos

\begin{abstract}
This article aims to analyze how some intellectuals associated with the Brazilian Estado Novo - Almir de Andrade, Rosário Fusco, Wilson Lousada and others - have promoted a teleological reading of the 1922 Modernism and sought to appropriate the regionalist novel of 1930 as a strategy for legitimizing the arrival and stay of Getúlio Vargas in power.
\end{abstract}

KEYWORDS: Novel of 1930; 1922 Modernism; Brazilian Estado Novo; Graciliano Ramos 
No livro 1930: a crítica e o modernismo, João Luiz Lafetá procura examinar as facetas intra e extraliterárias do modernismo brasileiro. Com base em postulados extraídos do formalismo russo, faz uma distinção entre o "projeto literário" (de rupturas operadas na linguagem) e o "projeto ideológico" (de reorientação do pensamento) preconizados pelo movimento. Norteado dialeticamente por tal distinção, o crítico toma a literatura produzida após 1922 e aquela posterior a 1930 como partes de um mesmo todo. Contudo, não deixa de pontuar que os elementos enfatizados por uma e outra seriam diferentes: enquanto na fase heroica estava em primeiro plano a "revolução na literatura" (antimimetismo, euforia e luta contra o passadismo), nas produções que se seguiam à revolução de 1930 avultava a "literatura na revolução" (problematização da realidade brasileira e agudização disfórica da consciência política).

Ao considerar o modernismo como um processo bifásico, Lafetá argumenta que haveria uma mudança de ênfase na passagem da década de 1920 para a de 1930, em virtude da vigência de condições políticas especiais em cada contexto. ${ }^{1}$ Contudo, indiretamente estabelece o modernismo de 1922 como marco zero, ponto a partir do qual se instauraria a engrenagem dialética da distinção entre "projeto estético" e "projeto ideológico" na moderna literatura brasileira:

Tendo completado de maneira vitoriosa a luta contra o passadismo, os escritores modernistas e a nova geração que surgia tinham campo aberto à sua frente e podiam criar obras mais livres, mais regulares e seguras. Sob esse ângulo de visão, a incorporação crítica e problematizada da realidade social brasileira representa um enriquecimento adicional e completa — pela ampliação dos horizontes de nossa literatura — a revolução na linguagem.

Conforme indicado, tal formulação permite divisar a precedência da primeira fase (marcada pela "revolução na linguagem") em relação à segunda (de "incorporação crítica e problematizada da realidade social brasileira"): esta seria um complemento

1. Nos anos 1920, destaque para o início da ascensão da burguesia e das classes médias (apesar da manutenção da força do poder oligárquico), num contexto de modernização e de implantação do capitalismo no país. Nos anos 1930, ênfase no recrudescimento da luta ideológica e na ampliação da consciência de luta de classe (Cf. LAfETá, João Luiz. 193o: a crítica e o modernismo. São Paulo: Duas Cidades; Editora 34, 2000, pp. 27-8). 
daquela. Não por acaso, Lafetá reprova a atenuação e a diluição da estética modernista de 1922 ao longo do decênio de 1930. Segundo ele, depois de colorir o "projeto estético", o "projeto ideológico" teria destituído a produção literária nacional do "sentido íntimo da modernidade". ${ }^{2} \mathrm{O}$ retorno do gênero romanesco ao arcabouço literário neonaturalista do século xix seria mostra desse aparente retrocesso. ${ }^{3}$ Nesse sentido, o crítico considera o romance de 1930, pautado pela consciência da função social da literatura, muitas vezes "tomada de forma errada", como um dos causadores "do desvio e da dissolução" das conquistas obtidas na fase heroica do movimento. ${ }^{4}$

Apesar de pontuar a oposição entre os dois referidos projetos, Lafetá reconhece apenas tangencialmente um movimento coletivo de recusa ao modernismo entre a geração de escritores que estreou nos anos 1930. Luís Bueno adota posição diversa em Uma história do romance de 30. Ao descer à arraia miúda da produção crítica e romanesca da época, o crítico tematiza a forte tensão entre a literatura de 1922 e aquela produzida depois da revolução de outubro. ${ }^{5}$ Em outras palavras, ele abdica do princípio de continuidade pacífica invocado por Lafetá. Em vez de considerar a existência de um único movimento dividido em duas fases, Luís Bueno parte do pressuposto de que estariam em jogo dois movimentos literários e geracionais distintos: o modernismo e o pós-modernismo (este último englobaria os artistas imediatamente situados após o modernismo de 1922).

2. LAfEtá, João Luiz. Op. cit., p. 34.

3. Porém, cabe considerar que o realismo dos anos 1930, calcado em dados econômicos e sociológicos, não seria, meramente, um anacronismo ou uma simples retomada conservadora da tradição romanesca do século XIX, mas sim a tradução, em termos narrativos ("projeto estético"), dos elementos arcaicos da modernidade brasileira, na qual a individualidade burguesa ainda não se encontrava resolvida. Tratase de uma literatura pontuada pela noção de "semi-historicidade", decorrente da decadência coetânea tanto da sociedade semifeudal no Nordeste como da sociedade semiburguesa no Centro-Sul (Cf. CARPEAUX, Otto Maria. “Romance brasileiro”. In: Ensaios reunidos (1942-1978). Rio de Janeiro: UniverCidade; Topbooks, 1999). Nesse sentido, em chave lukacsiana, predominam obras que enfeixam, sobretudo, sujeitos problemáticos e contradições sociais (negatividade), com privilégio não para a desrealização (da fase heroica), mas sim para o trabalho mimético.

4. Id., p. 36 .

5. Ao longo do texto, a expressão "Revolução de Outubro" refere-se ao movimento armado que depôs o então presidente da República, Washington Luís, e impediu a posse do novo chefe da nação, Júlio Prestes, eleito em 1930. Não se faz menção à "Revolução Vermelha” ou à “Revolução Bolchevique”, liderada por Vladimir Lenin em outubro de 1917. 
Não é muito fácil, no entanto, admitir uma continuidade dos projetos estético e ideológico de uma geração para outra de forma que a ênfase num ou noutro dê conta dos desacordos que separam essas duas gerações. Seria preciso saltar as enormes diferenças que há entre os intelectuais formados antes da Primeira Guerra e a dos formados depois dela. ${ }^{6}$

Ao enfocar o segundo grupo de escritores, Bueno argumenta que, depois da revolução de 1930, se haveria instaurado uma nova visão de Brasil, cujas diretrizes preconizavam um deslocamento no plano ideológico. Nesse momento, em oposição ao período anterior, ganha espaço a "pré-consciência do subdesenvolvimento", numa conjuntura disfórica pautada pelo adiamento da utopia e pelo "mergulho na incompletude do presente". Tal reorientação político-intelectual, norteada pela descrença na positividade da modernização, resultaria em formas de ação diversas das anteriormente utilizadas, redundando, até mesmo, em outras opções estéticas. Segundo o crítico, o predomínio de romances interessados em esquadrinhar as misérias nacionais, ao invés da prevalência da poesia, seria mostra suficiente disso. ${ }^{8}$

Quando se aprofunda o método heurístico levado a cabo por Bueno, de examinar de perto a produção crítica do período, mais do que a oposição entre projetos distintos, observa-se a prevalência de certa leitura teleológica a respeito do modernismo de 1922, cuja orientação se dá no sentido oposto à perspectiva genealógica preconizada por Lafetá: enquanto este toma o melhor da produção dos anos 1930 como uma espécie de coroação do "primeiro" modernismo (a consagração, em culto genealógico, da revolução estética proposta na fase heroica), os romancistas de 30 (sejam realistas, sejam intimistas) irão considerar, em visada teleológica, suas próprias realizações como o ponto de chegada de um processo apenas esboçado de modo incipiente pelos agitadores da Semana de Arte Moderna.

6. Bueno, Luís. Uma história do romance de 30. São Paulo: Edusp; Campinas: Editora da Unicamp, 2006, p. 58.

7. Bueno lança mão do conceito de "pós-utopia", retirado de Haroldo de Campos, para explicar a transição da euforia dos anos 1920 para a disforia da década de 1930. Segundo o crítico, à arte deste último período não caberia abraçar qualquer projeto utópico, colocando-se como "algo muito diverso do que os modernistas haviam levado a cabo" (BUENO, Luís. Op. cit., p. 68).

8. Id., p. 66. 
Todavia, quanto a esse último posicionamento, se era adotado por um Graciliano Ramos $^{9}$ e por um Octávio de Faria, ${ }^{10}$ também encontrava ressonância no bojo da própria retórica oficial do Estado Novo, em discursos que procuravam articular política e literatura com o fito de legitimar os golpes de 1930 e de 1937. Em outras palavras, não só realistas e intimistas, ${ }^{11}$ mas também intelectuais diretamente ligados à formulação e difusão do arcabouço ideológico da ditadura getulista recusavam qualquer precedência totalizadora que os filiasse à fase heroica do movimento modernista. Bem verdade que, no delineamento histórico que construíam da vida intelectual do país, em geral, o

9. Em diversas ocasiões, o escritor alagoano insurgiu-se contra a leitura do cânone proposta pelos artistas da chamada "fase heroica" do modernismo de 1922. Segundo Graciliano, tais literatos "cabotinos" passaram a condenar, de forma apressada e sem o devido exame, determinadas obras, simplesmente pelo fato de terem sido escritas em "português direito", promovendo a ideia de que sintaxe e bom gosto seriam incompatíveis. Ao mesmo tempo, também descarregava sua artilharia contra as próprias produções modernistas. Seu principal alvo eram as inovações linguísticas propostas por tais escritores, quase sempre em desarmonia com a linguagem popular, invocada por eles mesmos, contraditoriamente, como "autoridade suprema" em qualquer discussão sobre a "realidade nacional" (RAmos, Graciliano. Linhas tortas. Rio de Janeiro: Record, 2005, p. 388). O único mérito que reconhecia ao movimento de 1922 teria sido usar a picareta e espalhar o terror entre os antigos cultores da língua, deixando o terreno mais ou menos desobstruído para a geração de 1930 (RAmos, Graciliano. Conversas. Organização de Thiago Mio Salla e Ieda Lebensztayn. Rio de Janeiro: Record, 2014, p. 215). Nesse sentido, reduz a importância do modernismo apenas à condição de preparador de algo maior, que lhe sucederia.

10. No polêmico quarto número da revista Lanterna Verde, organizado por Tristão de Athayde, Octávio de Faria chega a afirmar que o modernismo de 1922 nem chegaria a ter existido. Se recusa a fase inicial do movimento, descrita como "simples imitação dos excessos estrangeiros, cópia dos hinos à máquina de Marinetti, bebedeiras de klaxons [...], desvairismos de todas as espécies e sem o menor sentido", valoriza o segundo momento modernista, no qual avultaria, de modo construtivo, o interesse pelo país. Todavia, diferentemente dos autores nordestinos, a historicização literária proposta por Faria colocava como ponto de chegada não o romance regionalista (rebaixado pelo aparente "exagero do característico e do regional"), mas sim o romance psicológico, cujo foco central, para além de imperativos historiográficos, geográficos e sociológicos, estaria no "humano" (FARIA, Octávio de. "Mensagem post-modernista". Lanterna Verde, Boletim da Sociedade Felipe d'Oliveira, Rio de Janeiro, n. 4, nov. 1936, pp. 62 e 65).

11. Não se trata de categorias esquemáticas e estanques. No caso do já mencionado Graciliano Ramos, por exemplo, por mais que, sobretudo em seu discurso crítico, ele se coloque deliberadamente entre os realistas nordestinos, seu romance Angústia, em especial, privilegia elementos caros aos intimistas, com destaque para o mergulho introspectivo na vida do personagem Luís da Silva (Bueno, Luís. Op. cit., pp. 621-2). 
marco de 1922 estava presente como o momento de "libertação das cadeias do espírito" e de mergulho na "essência da brasilidade". Contudo, no lugar de conferir importância às "origens" do ambiente político e artístico em que viviam, preferiam, em atitude autoafirmativa, conceder relevância a suas próprias realizações, tomando-as como ponto culminante ("fim") de um processo, cujo marco fundador se encontrava, de fato, em 1930.

\section{A LEITURA TELEOLÓGICA DO MODERNISMO DE 1922}

Nesse sentido, se Lafetá destaca o "projeto estético" e o "projeto ideológico" do modernismo brasileiro, pode-se distinguir também o "projeto político" que subjaz às diferentes propostas e iniciativas (sejam elas progressistas, sejam conservadoras) do movimento. Conforme observou Pécaut, o modernismo teria ressaltado a indissociabilidade entre os planos cultural e político. ${ }^{12}$ Sobretudo a partir da década de 1920, já se mostrava imperativo que certo nacionalismo de caráter passivo, pautado tão somente pela contemplação das belezas naturais do país, cedesse lugar a um nacionalismo propositivo, orientado pelo conhecimento efetivo, a um tempo específico e multifocal, das matérias ditas brasileiras. Assim, observa-se o desdobramento da atuação da intelectualidade: a recuperação do passado deveria apontar para aquilo que, sob sua condução, a pátria viria a ser. Saber e poder se imbricavam na ânsia dos intelectuais por influir nos destinos do país, apontar caminhos e forjar políticas de ação. ${ }^{13}$ De um ponto de vista amplo, tal postura assertiva e o interesse por matérias nacionais, macrocaracterísticas dos diferentes projetos modernistas, ganharam respaldo governamental ao longo dos anos 1930, no processo de construção e reaparelhamento do Estado. Em certo sentido, o próprio contexto brasileiro, pautado pela incipiência e pelo caráter pouco diferençado das instituições culturais, levaria os intelectuais a reorientarem seus investimentos e projetos na direção governamental. Paralelamente, nesse jogo simultâneo de engajamentos, apagamentos e apropriações, o Estado acabaria por incorporar, mesmo à revelia de certos atores, muitas das propostas modernistas (desbastadas de suas rebarbas) que

12. PÉcaut, Daniel. Intelectuais e a política no Brasil. São Paulo: Ática, 1990, p. 27.

13. Luca, Tania Regina de. A Revista do Brasil: um diagnóstico para a (N)ação. São Paulo: Editora da Unesp, 1999, p. 41. 
privilegiavam a organicidade e a incorporação de elementos nacionais. ${ }^{14}$ De modo geral, observa-se o desdobramento de um processo amplo de homogeneização e naturalização de um passado conscientemente selecionado, tendo em vista o construto da "legitimidade emocional", norteadora do nacionalismo propagandeado pela ditadura varguista.

Não por acaso, o próprio Getúlio Vargas, em discurso pronunciado na Universidade do Brasil, em 28 de julho de 1951, tomava a Semana de 1922 como marco inicial de um processo de recuperação da brasilidade e de despertar da literatura para uma "vida nova", que somente seria concretizado pela Revolução de 1930. Ao estabelecer tal relação de continuidade, sinalizava que as propostas modernistas valeriam tão somente enquanto prenunciadoras das conquistas a serem efetivadas por seu governo:

As forças coletivas que provocaram o movimento revolucionário do modernismo na literatura brasileira, que se iniciou com a Semana da Arte Moderna de 1922, em São Paulo, foram as mesmas que precipitaram, no campo social e político, a Revolução de 1930. A inquietação brasileira, fatigada do velho regime e das velhas fórmulas, que a rotina transformara em lugar-comum, buscava algo de novo, sinceramente nosso, mas visceralmente brasileiro. Por outro lado, a revolução econômica do mundo, o progresso técnico industrial, a ascensão do proletariado urbano como força ponderável na decisão dos fatos políticos estavam a exigir nova estruturação da sociedade e novas leis, capazes de atender com eficiências a essas necessidades. ${ }^{15}$

Ao eleger tais marcos temporais como representativos e depois concatená-los numa sequência linear (e aparentemente irreversível), o presidente construía uma relação necessária entre momentos distintos a partir de uma perspectiva teleológica e legitimadora. Nesse processo de construção de inteligibilidade, o modernismo perdia sua autonomia e força, passando a ser visto apenas como iniciativa inacabada e incompleta, que viria a ser concretizada posteriormente, em etapas distintas, durante a permanência de Vargas no poder. A partir de 1930, o chefe da nação faz referência a uma suposta convergência entre as iniciativas literárias e políticas, na qual o potencial destrutivo dos revoltosos da Semana de Arte Moderna teria sido limado em prol de propostas mais construtivas e conciliatórias:

14. PÉcaut, Daniel. Op. cit., p. 89.

15. VArgas, Getúlio. O governo trabalhista do Brasil. Rio de Janeiro: José Olympio, 1952, p. 382. 
[...] passados os primeiros instantes e obtidas as primeiras conquistas, um e outro se fundiram num movimento mais amplo, mais geral, mais completo, simultaneamente reformador e conservador, onde foram limitados excessos, polidos os extremos sempre cheios de asperezas e harmonizadas as tendências mais radicais e divergentes. ${ }^{16}$

Para Vargas, política e cultura formavam um todo inseparável e interdependente. Partindo de tal premissa, o presidente procurava tanto explicar como justificar o "magnífico surto nas letras brasileiras" durante a década de 1930, no qual "uma plêiade numerosa de valores novos trouxe a sua colaboração e entusiasmo criador e renovador a todos os departamentos da cultura". Segundo o autor de A nova política do Brasil, nunca a vida intelectual brasileira assistira a um período tão fértil e pujante, graças, sobretudo, à ação de seu governo, que teria dispensado "simpatia, compreensão, apoio cotidiano, estímulo e liberdade" à cultura nacional. ${ }^{17}$ Portanto, ao se referir à produção artística feita depois de 1930, sua abordagem deixava de lado, voluntariamente, a censura praticada pelo Estado Novo. Ao mesmo tempo, concentrava-se em dados quantitativos, esquecendo-se também de que uma parcela razoável das obras lançadas no período obedecia a certo caráter pedagógico, condizente com as diretrizes da propaganda estatal. Esta, por sua vez, procurava controlar e enquadrar as versões possíveis e toleradas da "realidade" brasileira a serem veiculadas pelos diferentes discursos, cerceando e dirigindo o pluralismo das manifestações.

Tal perspectiva varguista que procurava estabelecer um elo de continuidade entre os marcos temporais de 1922 e 1930, transformados de simples datas em eventos acabados, bem como subordinar o primeiro momento ao segundo, já se encontrava presente nos textos dos diferentes ideólogos estadonovistas. No livro Política e letras, Rosário Fusco ${ }^{18}$ destacava que, se, por um lado, o modernismo teria imposto a necessidade de se conhecer a vida nacional, por outro, para atingir esse objetivo, o movimento valerase de uma atitude excessivamente destrutiva e iconoclasta, voltando-se, de maneira imoderada, contra tudo aquilo considerado passadista e tradicional. Segundo Fusco,

\footnotetext{
16. Id., p. 383 .

17. Id., p. 384 .

18. Poeta, ensaísta e romancista mineiro que integrou o grupo modernista de Cataguazes. Espécie de crítico literário oficial do Estado Novo, Fusco foi responsável pela seção "História Literária do Brasil" da revista Cultura Política. Na mesma publicação, estampou ensaios sobre a figura de Getúlio Vargas.
} 
com a chegada de Getúlio ao Catete, tal postura desmedida e irrefletida fora corrigida e substituída por outra mais construtiva e pacificadora:

O fato é que, ajustados os quadros políticos aos quadros sociais, a construção começou também no campo das letras. E logo após a vitória do movimento revolucionário de 1930, passamos a constatar o seguinte fenômeno: assim como a revolução política progredia, em espírito, recriando a alma do país, que anima as cidades e os campos, a revolução literária prolongava-se num silencioso, mas seguro, processus de evolução. ${ }^{19}$

Nesse sentido, o poeta de Cataguazes destaca que teria cabido à revolução de outubro a tarefa de garantir uma trégua na revolução literária iniciada em 1922. Conforme explica, a ação do Estado permitira que o país, enfim, reencontrasse seu caminho de equilíbrio, conscientização e valorização efetiva das matérias brasileiras, tanto em termos políticos quanto literários. Para Fusco, politicamente, o governo vitorioso procurara associar presente e passado num processo de "nacionalização de todas as nossas reservas"; e, literariamente, valorizar a busca do universal a partir do regional. Portanto, segundo tal perspectiva, o modernismo fora não só territorializado (com suas arestas devidamente aparadas) como também complementado pela obra de Getúlio.

Em inquérito sobre a produção literária brasileira, com destaque para o papel exercido pelo modernismo, realizado pela Revista do Brasil, nos anos 1940, Almir de Andrade ${ }^{20}$ adotava posicionamento semelhante. Segundo ele, o movimento teria sido essencialmente crítico, pois objetivara fazer uma revisão de valores e libertar a literatura de velhos esquemas. Contudo, nada produzira de grande ou duradouro. Sua marca teria sido a agitação, a efemeridade e a preparação do terreno para os autores posteriores, estes sim passíveis de serem chamados de criadores, na sua opinião. O futuro diretor de Cultura Política ${ }^{21}$ faz uma analogia entre o mundo natural e o universo literário para explicar seu argumento:

19. Fusco, Rosário. Política e letras. Rio de Janeiro: José Olympio, 1940, p. 75.

20. Ao lado de Francisco Campos e Azevedo Amaral, é considerado um dos principais ideólogos do Estado. Em março de 1941, a convite de Lourival Fontes, então diretor do Departamento de Imprensa e Propaganda (DIP), fundou Cultura Política: Revista Mensal de Estudos Brasileiros, publicação da qual foi diretor até outubro de 1945. Por meio de livros, artigos assinados e editoriais, Almir de Andrade buscou interpretar, com base em um projeto ideológico eminentemente cultural, a ditadura varguista.

21. Mesclando propósitos culturais e propagandísticos, Cultura Política: Revista Mensal de Estudos Brasileiros foi o periódico oficial de maior fôlego e envergadura ao longo da ditadura varguista: circulou 
$\mathrm{Na}$ evolução das artes, como na evolução das espécies biológicas, há movimentos dessa natureza: surgem tão somente para preparar o terreno aos movimentos seguintes, morrendo eles próprios sem deixar descendentes. Não perduram; entretanto, seria difícil compreender o aparecimento de muitas tendências posteriores, sem o trabalho de desbravamento e preparação por eles efetuado. ${ }^{22}$

Apesar de reconhecer o papel crítico e desbravador do movimento, frente ao "torpor" e à "inconsciência" da literatura do início do século, sobretudo no que dizia respeito ao tratamento das matérias tidas como brasileiras, sua postura é essencialmente questionadora da influência e da permanência do "espírito modernista" nas obras produzidas depois de 1930:

Nada mais falso do que julgar que o movimento modernista abriu uma era realmente nova em nossa literatura; nada mais artificial do que tomá-lo como marco divisório entre o presente e o passado. Do modernismo surgiram muitas tendências novas; mas depois do modernismo muitas outras tendências se estão formando em sentido contrário a ele, procurando reviver antigas tradições literárias ou se aproximando insensivelmente do equilíbrio e da disciplina dos modelos clássicos. ${ }^{23}$

Se retira do modernismo qualquer influência determinante, a não ser deixar o caminho livre para os romancistas e poetas de 1930, Almir destaca que coube aos acontecimentos políticos, iniciados com a revolução de outubro, a maior ascendência sobre a cultura nacional. Segundo ele, a ação estatal teria conferido uma tendência mais humana

mensalmente (com exceção dos números 50 e 51, trimestrais) de março de 1941 a outubro de 1945, em edições de caráter austero e livresco, quase sempre com mais de trezentas páginas. De orientação elitista, voltada preferencialmente aos grupos dominantes, procurava demonstrar, por meio de uma retórica nacionalista, permeada por argumentos de cunho filosófico e científico, o caráter inovador do Estado Novo brasileiro, justificando a suposta superioridade dele frente ao "falido" liberalismo. Nesse processo, a publicação também privilegiava uma visada cultural (daí a importância conferida à literatura e às outras artes) e a retomada, em tom erudito, da história do país como formas de atestar a aparente simbiose entre o regime e a "essência" da nação.

22. Andrade, Almir de. "Resposta de Almir de Andrade". Revista do Brasil, Rio de Janeiro, ano III, $3^{\text {a }}$ fase, n. 22, abr. 1940, p. 103.

23. Id., p. 106.

126 - SALLA, Thiago Mio. Literatura, política e legitimação institucional: o romance de 1930 
e nacional à produção artística, com ênfase na recuperação de aspectos históricos e sociológicos da vida brasileira.

Com relação ao referido caráter inacabado do modernismo, Wilson Lousada, responsável pela seção "Literatura de Ficção" da revista Cultura Política, assinalava que o movimento, obedecendo a certas circunstâncias dominantes no período posterior à Primeira Guerra Mundial, voltara-se para as tradições nacionais, em processo análogo ao realizado por outros povos naquele momento. Contudo, tratava-se de uma visada nacionalista imposta, sobretudo, pela conjuntura internacional, marcada ainda por um caráter "sentimental" e "livresco", que a distanciava da dita "realidade" brasileira. Conforme explica o articulista, tal cenário mudaria após 1930, quando teria surgido, "espontaneamente", outro nacionalismo mais "objetivo e realístico", condizente com as propostas da revolução de outubro:

Desta vez, é claro, influenciado por motivos de ordem interna, e bem mais nosso que o anterior, por isso que menos preso às escolas literárias estrangeiras, e menos intencional também. Surgiu espontaneamente, sem o ar de conspiração secreta tramada aos cochichos entre meia dúzia de escritores.

Foi para nós uma espécie de libertação espiritual sem os inconvenientes da que se realizou em 1922. Sem a necessidade imperiosa de escolher para acompanhar o ritmo exterior. Definimos nossa atitude perante nós mesmos, perante nossa consciência alertada e possivelmente justificada. ${ }^{24}$

Nesse sentido, o modernismo brasileiro é rebaixado tanto por partilhar de modelos importados (em outro texto Lousada destaca que ele seria tributário do modernismo francês e do pansexualismo de Freud), ${ }^{25}$ bem como por preterir uma abordagem sociológica e documental do país, a qual seria levada a termo, em contrapartida, pelos

24. LOUSADA, Wilson. "Literatura de Ficção (XVI)". Cultura Política, Rio de Janeiro, n. 16, jun. 1942, p. 237.

25. Tal referência a Freud já estava presente na crítica feita por Tristão de Athayde à rapsódia Macunaíma, de Mário de Andrade, quando do lançamento da obra em 1928 [Athayde, Tristão de (Alceu Amoroso Lima). "Macunaíma”. O Jornal, Rio de Janeiro, 9 set. 1928. In: RAmos JúNior, José de Paula. Leituras de Macunaíma: primeira onda (1928-1936). São Paulo: Edusp; Fapesp, 2012, pp. 261-71]. 
romances regionalistas de 1930. Portanto, o movimento de 1922 renegava aquilo que o autor chamava de "sensibilidade literária realista", em favor de certas "aventuras freudianas e pagãs", de experimentalismos "sem raízes profundas" e da ênfase no "esteticismo". Segundo ele ainda, os empreendimentos modernistas teriam realizado apenas uma incursão pela superfície da vida nacional, restringindo-se ao folclore e ao primitivismo, mas divorciando-se da terra e do povo.

\section{A APROPRIAÇÃO DO ROMANCE DE 1930}

Ao mesmo tempo, se o modernismo fora mais "subjetivo, cerebral e literário", a nova fase das letras nacionais, inaugurada pela revolução de 1930, destacava-se pela objetividade e pelo privilégio concedido ao tratamento das matérias nacionais. Para Lousada, ela teria revelado aspectos da "evolução social" do país até então desconhecidos, focando-se tanto no homem, como no ambiente pátrio, sem preterir os problemas tipicamente brasileiros, numa atitude marcada pela substituição do "conformismo" pela "ação". Portanto, as obras passavam, muitas vezes, a ser consideradas apenas enquanto documentos e instrumentos de intervenção em dada realidade ou, conforme sublinham as linhas que antecedem o segundo texto da seção "Literatura de Ficção", "a literatura deixou de valer apenas como literatura e passou a procurar uma base social definida". ${ }^{26}$

Tendo em vista a defesa de tal diretriz literária pautada pela vigência de certo protocolo "sociológico-regional", não por acaso os romances regionalistas de 1930 ocupavam um lugar de destaque nas formulações dos ideólogos estadonovistas. Na opinião deles, tal vertente da literatura brasileira ajustava-se perfeitamente aos novos tempos anunciados pela revolução de outubro e, em seguida, pelo Estado Novo. Segundo o discurso oficial, enquanto os modernistas teriam adotado uma perspectiva "falsa", tachada de excessivamente "literária" (apesar da atenção dedicada a matérias brasileiras), os romancistas surgidos depois de 1930, mais apegados ao povo e a terra, não teriam fugido às demandas do real e, consequentemente, a suas funções frente à pátria, com destaque para a construção da unidade nacional a partir do tratamento de matérias regionais (sobretudo de matriz rural), num processo de incorporação simbólica de diferentes partes e tipos do país.

26. LousAdA, Wilson. "Literatura de Fiç̧ão (II)". Cultura Política, Rio de Janeiro, n. 2, abr. 1942, p. 261. 
Referindo-se à produção cultural pós-1930, Rosário Fusco sublinha que o enfrentamento da "realidade", por diferentes artistas e pesquisadores, constituíra-se no fator mais representativo da produção intelectual brasileira desse momento, em oposição ao "modernismo intencional", "exibicionista" e de "convenção" da fase anterior:

Sociólogos e romancistas passam a valorizar o documento, contrapondo-o, à imaginação pura e simples. Fase de estudos objetivos, todos querem contribuir para o maior e melhor conhecimento de nossas realidades. E se Gilberto Freyre confirma, em fortes ensaios de interpretação social, o Nordeste que José Lins do Rego descreve nos seus apreciados romances, com a decadência do banguê e o consequente esfacelamento da nobreza rural nascida à sombra do engenho, o próprio presidente da República se faz novo bandeirante para recomendar, como sociólogo e como homem de governo, a marcha para o oeste, numa primeira tentativa para o aniquilamento do latifúndio e a disseminação da pequena propriedade; incrementando o plantio de novos centros de vida rural, fomentando o intercâmbio entre o sertão e o centro, o comércio das populações meridionais com os agregados sociais dos desertos geográficos, que morrem de fome demográfica; ajudando a produção agrícola, rasgando estradas, fundando escolas, revolvendo o solo. ${ }^{27}$

Novamente, o poeta de Cataguazes pretende apresentar os rumos da vida literária do país, pós-revolução de outubro, como uma consequência da política getulista, algo que já estaria presente na própria eleição do marco temporal de 1930, como ponto de inflexão das letras nacionais. Segundo ele, o governo Vargas teria conferido um "sentido objetivo" ao estudo da realidade brasileira, do qual os escritores, sobretudo os nordestinos, teriam se aproveitado para compor livros voltados ao social, em que a "imaginação contava pouco". Nessa atitude de vinculação entre política e artes, Fusco não deixava de ressaltar a perspectiva regionalista e o apego à terra, presentes nas obras de tais escritores, como componentes de um movimento maior de recuperação e valorização da nacionalidade.

Depois de afirmar que o movimento revolucionário de 1930 fora o fator "mais considerável na transformação sofrida pelas nossas letras", o já citado Wilson Lousada alçava os romances Menino de engenho, Os Corumbas, S. Bernardo e O quinze à condição de espelhos de "uma realidade que, nos anos anteriores por falta de ambiente espi-

27. Fusco, Rosário. Op. cit., pp. 78-9. 
ritual receptivo, nunca poderia ser entendida em seu verdadeiro alcance". ${ }^{28}$ Segundo ele, tais autores teriam passado a se apoiar em aspectos físicos, humanos e sociológicos da vida brasileira, tendo em vista o estabelecimento de um contato "profundo" entre "forças intelectuais e sociais". Nem mesmo o "realismo cru" e o pessimismo acentuado de alguns escritores seriam vistos como problemas. Tais opções se justificariam enquanto componentes de certa busca nacionalista que reivindicava a procura "em nós mesmos das causas e finalidades de todas as dúvidas, erros e inquietações" ${ }^{29}$ Logo, seria um sinal de vida, de "pesquisa consciente da realidade nacional" e de "vontade construtiva".

Esse movimento de recuperação e estudo da vida nacional passava antes pela abordagem das matérias típicas das diferentes regiões brasileiras. O próprio Lousada afirmava, por exemplo, que

[...] um romancista mineiro, por exemplo, não tem argumentos para resumir, na sua gente, toda a alma coletiva do Brasil, tão rica e expressiva nas suas diversas manifestações de caráter regional. Nem o romancista gaúcho, amazonense, pernambucano ou paulista. Cada um deles, portanto, terá de conservar suas raízes características, próprias, sua fisionomia peculiar, sua tradição incorporada ao meio social que trabalhou e moldou..$^{30}$

Segundo ele, tendo como base o pensamento de Oliveira Viana, o Brasil não formava um bloco único e indiviso. Na composição heterogênea da nação, pesavam questões específicas referentes às variações do meio físico e social, da história de constituição dos diferentes grupos populacionais, bem como do "caldeamento dos elementos étnicos". Nesse sentido, para o articulista, seria inútil falar em escritores brasileiros (em sentido geográfico), uma vez que considerava o regionalismo como veículo para a realização artística em termos nacionais.

Sabendo-se do caráter autoritário e centralizador do Estado Novo, pode soar estranha a defesa dessa perspectiva localista nas páginas de Cultura Política. No entanto, conforme explica José Lins do Rego, em artigo sobre Gilberto Freyre, tal orientação, formulada, sobretudo, pelo movimento regionalista do Recife, incidia apenas sobre o plano artístico. No plano político, ela respeitava a concentração de poder nas mãos do

28. Lousada, Wilson. "Literatura de Ficção (II)". Cultura Política, Rio de Janeiro, n. 2, abr. 1942, p. 262.

29. Id., p. 263.

30. Lousada, Wilson. "Literatura de Ficção viı". Cultura Política, Rio de Janeiro, n. 7, set. 1941, p. 292. 
presidente imposta pela ditadura varguista, mostrando-se contrária ao estadualismo que vigorara durante a Primeira República e fora tão combatido pelo regime de 1937:

Ser da sua região, de seu canto de terra, para ser-se mais uma pessoa, uma criatura viva, mais ligada à realidade. Ser de sua casa para ser intensamente da humanidade. Nesse sentido, o regionalismo do Congresso do Recife merecia que se propagasse por todo o Brasil porque é essencialmente revelador e vitalizador do caráter brasileiro e da personalidade humana. Com um regionalismo desses é que poderemos fortalecer ainda mais a unidade brasileira. Porque cultivando o que cada um tem de mais pessoal, de mais próprio, vamos dando mais vida ao grupo político, formando um povo que não será uma massa uniforme e sem cor. $^{31}$

Entre as regiões do país, o Nordeste distinguia-se para Lousada como um espaço onde, obrigatoriamente, a "realidade" se imporia a seus habitantes, fossem eles homens comuns na luta diária pela sobrevivência, fossem romancistas na escritura de seus livros de matiz regionalista. Para estes últimos, o "realismo da terra" apresentava-se tanto como um leitmotiv quanto como uma necessidade física. Portanto, fugir dele seria impossível. O grande problema surgia quando os autores lhe conferiam caráter exclusivo, o que redundava em obras excessivamente descritivas e exteriorizadas, mas pobres em aspectos humanos de matriz "universal". Nesse sentido, Graciliano Ramos sobressaía aos olhos de Lousada como um legítimo criador; escritor de um "regionalismo justo", pois conseguira fixar suas criaturas dentro da paisagem, sabendo ao mesmo tempo ser "localista" e projetar-se além dos limites sertanejos..$^{32}$

Em outro sentido, pensando na própria estruturação do texto, Almir de Andrade refere-se a certo equilíbrio entre o clássico e o moderno na obra de Graciliano, vista enquanto parte do romance social de "expressão genuinamente brasileira" que não prescindia de "um vigoroso esforço de investigação subjetiva". ${ }^{33}$ Ele considera o fazer artístico do autor alagoano como resultado de um processo de lenta depuração e aper-

\footnotetext{
31. Rego, José Lins. Gordos e magros: ensaios. Rio de Janeiro: C.E.B., 1942, pp. 130-1.

32. Id., p. 235.

33. Andrade, Almir. “Tendências atuais do Romance Brasileiro". Lanterna Verde, Rio de Janeiro, n. 5, jul. 1937, p. 39.
} 
feiçoamento, que o colocava além da perspectiva simplesmente "libertadora" e "destrutiva" do modernismo:

Graciliano Ramos, por exemplo, traz a marca indiscutível da influência modernista como José Lins do Rego, como José Américo de Almeida, como Jorge Amado, como muitos outros. Entretanto, há no romance de Graciliano um esforço de cristalização nitidamente "contrário" ao do movimento modernista: seu estilo castigado, burilado, expurgado está bem distante da liberdade de expressão, do primitivismo, do naturalismo, do "brasileirismo" dos escritores modernistas; seus capítulos, cimentados e estruturados, revelam uma disciplina espiritual, uma disciplina de forma, de estilo, de concepção, que é, em si mesma, a negação do espírito do modernismo. ${ }^{34}$

Dessa maneira, ao mesmo tempo em que não empreendera uma volta aos modelos clássicos, Graciliano se teria afastado das propostas do movimento de 1922, que, segundo Almir, lhe teriam inspirado apenas os temas dos livros e, mais especificamente, favorecido alguns aspectos elocucionais de sua prosa. Na opinião do crítico, o trabalho empreendido pelo escritor alagoano de vasculhar a "alma nacional" poderia ser tomado como uma "contrarreação individual antimodernista", das mais significativas da literatura brasileira, pós-1930.35

\section{ESTADO NOVO: CONTROLE E CONVERSÃO DA “PÓS-UTOPIA”}

Em linhas gerais, a iniciativa governamental de rebaixar o modernismo de 1922 e elevar o romance regionalista de 1930 fazia parte de um processo amplo de tutela e enquadramento dos diferentes projetos em curso no campo cultural. Dirigindo o horizonte de leitura e a interpretação da "brasilidade", o Estado, por meio de seus diferentes atores e canais de comunicação, procurava se apresentar tanto como regulador quanto como autenticador das propostas colocadas em jogo.

34. Id. "Resposta de Almir de Andrade". Revista do Brasil, Rio de Janeiro, ano III, $3^{\text {a }}$ fase, n. 22, abr. 1940, p. 106.

35. Ibid. 
De acordo com essa perspectiva, o localismo do romance de 1930 não se configurava necessariamente como um problema para o poder central. Para além de produzir uma vigorosa força de oposição à visão unificadora e totalitária do regime, ${ }^{36}$ tal visada regionalista acabava por promover a incorporação simbólica do hinterland brasileiro, pois produzia um saber e uma dizibilidade específica sobre o longínquo mundo sertanejo que, segundo a ladainha oficial, ainda fugia ao "ímpeto renovador da civilização litorânea". ${ }^{37}$ Além disso, no que diz respeito apenas ao plano artístico, a revista Cultura Política, em consonância com a orientação preconizada pelo movimento regionalista do Recife, considerava que os escritores só poderiam realizar-se, em termos nacionais, por meio do regionalismo. ${ }^{38}$

No caso específico do romance nordestino, pautado pela crítica social, ao invés de censurar obras, passava-se a procurar nelas apenas a porção de realidade que lhes coubesse $^{39}$ (e que conviesse ao poder). Nesse cenário, abordar o sertão miserável, tal como realizado por Graciliano em Vidas secas, não se constituía numa ameaça, muito pelo contrário, pois o próprio Estado, ancorado em sua máquina propagandística, se colocava como o suposto iniciador do movimento de descida aos "porões da realidade nacional", num processo de tomada de "consciência" do país. O mesmo ocorreria com o tratamento do autoritarismo em S. Bernardo (ainda no âmbito da obra do referido escritor alagoano). Ao tratar do tema, o artista teria descrito um problema social e político, cujas origens residiam no caráter antidemocrático das oligarquias liberais, em fase de superação, tendo em vista a aparente atuação do regime, convenientemente pautada pelo combate ao liberalismo da Primeira República. Em outras palavras, a onívora retórica oficial punha-se a converter a "pós-utopia" dos romancistas de 1930 numa utopia conservadora, tecnicista e totalizadora.

Entretanto, se houve tal esforço discursivo por parte de agentes vinculados ao aparato do Estado, a permanência e a intensificação dos dilemas trazidos pelo romance de 1930, antes e depois de 1945, revelariam a força e a amplitude de tal produção ficcional para além dos tentáculos e das balizas disciplinadoras estadonovistas. E, para

\footnotetext{
36. Bueno, Luís. Op. cit., p. 8o.

37. ESCRITOR e romancista... Cultura Política, Rio de Janeiro, ano 1, n. 1, mar. 1941, p. 236.

38. LousadA, Wilson. "Literatura de Ficção (vir)". Cultura Política, Rio de Janeiro, n. 7, set. 1941, p. 292.

39. FARIA, Daniel. "Realidade e consciência nacional. O sentido político do modernismo". História, São Paulo, v. 26, n. 2, 2007, p. 398.
} 
continuar ainda com o caso específico de Graciliano Ramos, se o temário inconformista e contundente de sua prosa já se colocava como uma linha de fuga difícil de ser domesticada (ainda mais por um regime político que manteve intocada a desigualdade das estruturas social e econômica brasileiras), a fatura literária por ele operada hiperdimensionava a construção do sentido como negatividade, bem como incorporava de modo orgânico os impasses da vida nacional ao plano da arte romanesca..$^{40}$

Thiago Mio Salla é professor da Escola de Comunicações e Artes da USP.

40. Bueno, Luís. Op. cit., p. 664. 